\author{
Grzegorz Sztabiński \\ (1) https://orcid.org/0000-0003-2888-498X \\ Strzemiński Academy of Art in Lodz \\ grzegorzsztabinski@op.pl
}

\title{
WHY DO WE NEED THE TERM “ART”?
}

\begin{abstract}
The article reflects on the contemporary situation in which the term "art" is broadly used, albeit without attempting to clarify its meaning or define it. This situation concerns both the area of aesthetics, where the deliberations on the concept of art have been abandoned for several decades, as well as the statements of critics and artists.

The starting point of the reflections presented here is the situation that occurred in the 1950s and 1960s. In the aesthetic thought there appeared views pointing to the indefinability of the term "art". (e.g. the stand of Morris Weitz) and the tendencies to indicate other usages of this term, than cognitive - to consider its evaluative, persuasive, etc. character, etc. In the 1990s, Arthur C. Danto's texts were an important contribution to this issue, commenting on the subject in the context of his theory of the "end of art". That "end" did not mean the end of artistic creativity, but only a change consisting in the end of the era of art as a theoretical problem. In the 20th century, both in created works and in written texts, attempts were made to establish what "true art" is. Today, however, all meanings of the word "art" become important. Artistic life, according to Danto, is therefore more peaceful, free from "ethnic cleansing".

How, then, do we motivate the inclusion of particular practices in the area of art? I believe that it often happens on a similar basis to playing dominoes. I illustrate this thesis with the use of the Polish example - the concept of "art with community" implemented since 2011 in the Warsaw district of Ursus. The text ends with reflections on contemporary "theorizing with uncertainty". There is an assertion that the term "art" plays an integrating role in the face of various activities, for which otherwise it would be difficult to find an appropriate category.
\end{abstract}

Keywords: indefinability of the term "art", "end of art" (A. Danto), art after the end of art, theorizing with uncertainty, "art" as an integrative category

The avant-garde of the first half of the 20th century has revolutionized the art scene but there has never been any broader discussion on the nature of the general concept of "art". As researchers of that era emphasize, the term "new art" was often used to distinguish avant-garde works from old ones, but it was a decision based not so much on an analysis of differences in relation to the 
way artistic creativity was understood, but on a desire to mark the separation or distinction from what had been earlier. A similar situation occurred in the case of more radical decisions, such as the Dadaistic "anti-art" or the Constructivist idea of "non-art". In these cases, it was not only a matter of rejecting old art and art in general, but also of taking an interest in the problems of everyday life, politics, etc. Both the term "art" and the associations it evoked seemed inappropriate in such cases because of the conviction that artistic and aesthetic autonomy was outdated in the new, planned cultural reality. ${ }^{1}$ The concept of "art" came into the focus in the 1960s and 1970s. This issue manifested itself most markedly - as it was part of the program - in the first phase of Conceptualism, when, as Joseph Kosuth put it, art was meant to be a "definition of art". However, it also appeared within the framework of the activities of representatives of trends different or opposing to Conceptualism, such as pop art, happening, land art, minimal art, etc. In the post-artistic tendencies of the time, questioning or denying art did not occur spontaneously or in a manner conditioned only by considerations associated with the belief that it was life that dominated, but often consisted in systematic contemplation of reasons for leaving the scope of what was artistic. ${ }^{2}$ This interest in the concept of "art" was also discernable at the turn of the 1970s and 1980s. The emergence of "wild" painting and sculpture, trans-avant-garde, etc. was explained as the "return of art to its territory", as an expression of freedom manifested through resignation from the imperative of change imposed by the avant-garde. ${ }^{3}$

A markedly increased interest in the concept of "art" in the second half of the 20th century could also be observed in aesthetics. Previously, art philosophy had focused on the artistic creations themselves and the experiences they evoked. During this period, there was a concentration on the theoretical and conceptual aspects. Usually, however, this change is not translated as a reaction to the tendencies occurring in contemporary art, but indicates other, internal aesthetic reasons. The basic one would be the influence of analytical philosophy. The famous book edited by William Elton Aesthetics and Language 4 is considered

1 Peter Bürger links this issue with the negation of the autonomy of art and the situation in which works of art "are no longer signs pointing to reality, they are reality," Theory of the Avant-Garde, transl. from the German by M. Shaw, Manchester University Press - University of Minnesota Press, Minneapolis 1984, p. 78. The exception is Marcel Duchamp's output. This may have been one of the reasons why it became as subject of particular interest in the second half of the 20th century.

2 Stefan Morawski thoroughly analyzed these issues in many articles and in his book Na zakręcie. Od sztuki do posztuki, Wydawnictwo Literackie, Kraków 1985.

3 Achille Bonito Oliva wrote about it in his text Points of recent history (catalog Nouvelle Biennale de Paris 1985, Electa Moniteur, Milan-Paris 1985.

4 Aesthetics and Language, ed. W. Elton, Basil Blackwell, Oxford 1954. 
groundbreaking in that regard. The authors of texts agreed that a change should be effected in aesthetics just as in other areas of science, focusing on the analysis of the language used. The failure of the previous aesthetic theories, it was claimed, had sprung from methodological and terminological errors - vagueness of applied terminology, speculative, unverifiable and non-physical concepts, etc. One of the principal terms that underwent such analytical treatment was "art". Attention was drawn to its imprecision and the usual assumption that the existence of a word is supposed to indicate that there are corresponding objects. For example, the existence of the noun "work of art" was intended to confirm the belief that there is a specific group of objects to which the term applies and whose specific characteristics can be determined. The search for essential common features, characteristic of all works of art, has been one of the main topics of aesthetic research over the centuries. This trend was defined as an essentialist fallacy, which consists in the belief that the phenomenon under investigation has its own essence, which can be determined. Its discovery is the main goal of cognitive endeavors, because without its definition the use of an appropriate term is imprecise, inconsistent and liable to be subject of numerous controversies and contradictions. ${ }^{5}$ This was the fate of disputes on the grounds of aesthetics. Over the centuries, attempts have been made to establish the essence of art, but, as authors of articles in the anthology pointed out, this did not have the desired effect. Therefore, turning to the study of the concepts used in aesthetics, they wanted to determine whether the essentialist approach makes it possible to define the meaning of the word "art". The conclusion was that it was not impossible to establish the universal nature of art, and its full, real definition cannot be formulated. One can only, as Paul Ziff pointed out when developing this view in other texts, give partial definitions referring to what was considered art in a particular era, on the grounds of a certain style, direction, etc. The only thing that can be done is to give partial definitions referring to what was considered art in a particular epoch, on the grounds of a certain style, direction, etc., in order to make it easier for the viewer to understand what was going on. This author believed that in aesthetics there are many notions to which only "imaginary objects" correspond. "Perhaps the most persistent myth in present-day aesthetics is the notion that when we discuss a work of art we are not talking about a painting but about some 'illusory' or 'imaginary' thing sometimes called the 'object of art' or the 'aesthetic object'". ${ }^{6}$

Authors who contributed to Aesthetics and Language represented a cognitive approach to the term "art". Aesthetics was treated as one of the areas of scien-

5 Bohdan Dziemidok writes about this problem in his book Gtówne kontrowersje estetyki wspótczesnej, Wydawnictwo Naukowe PWN, Warszawa 2002, p. 109.

6 P. Ziff, Art and the Object of Art, in: Aesthetics and Language, op. cit., p. 170. 
ce, so the proposed treatments thereof were analogous to those which representatives of analytical philosophy recommended for other areas of knowledge. It was mentioned, however, that in addition to the analytic definitions, synthetic (projecting) definitions, for example, are possible. The 'terminological projects' is defined as such and thus proposes a new understanding of the term. However, the issue was considered primarily in the critical context - it was argued that in aesthetics, definitions that give the impression of analytic are in fact proposals for a new, extended, narrowed or even changed understanding of the word.

The cognitive attitude dominated the discussions on the concept of "art" in the 1960s and 1970s. At that time, it was debated not just how to define this concept, but also whether such an endeavor was possible at all, assuming the actions were logically correct. One of the most important texts that addressed this problem is an article by Morris Weitz, in which the author points out that in aesthetics the use of the term "art" has always been associated with a specific theory. He writes that "theory has been central in aesthetics", and "Its main avowed concern remains the determination of the nature of art which can be formulated into a definition of it." ${ }^{7}$ A theory, in its broad sense, is a systematized set of theorems concerning a particular field. In this case, the field is art, and the task of theory is to define its essence, which can be expressed in the form of a definition. As Weitz specifies: "It construes definition as the statement of the necessary and sufficient properties of what is being defined, where the statement purports to be a true or false claim about the essence of art, what characterizes and distinguishes it from everything else." 8 According to the American author, such theories were both great aesthetic concepts, such as formalism, emotionalism, intuitionism, voluntarism, etc., as well as less influential ones, associated with the names of individual authors. In all of them, in his opinion, it was a question of formulating more or less precisely and openly what the meaning of the word 'art' was. Thus, all of them were subject to evaluation related to whether they are false or true and whether they are adequate, i.e. whether they omit any necessary or sufficient attribute of the defined phenomenon. The reason why Weitz's article provoked such a heated debate was the claim that in the case of art this task is impossible to execute. The author stated that a person who sets themselves such a task "radically misconstrues the logic of the concept of 'art'." $\mathrm{He}$ wrote: "Art, as the logic of the concept shows, has no set of necessary and sufficient properties, hence a theory of it is logically

7 M. Weitz, The Role of Theory in Aesthetics, "The Journal of Aesthetics and Art Criticism" 1956, No 1, p. 27.

8 Ibid., p. 27.

9 Ibid., p. 28. 
impossible and not merely factually difficult." 10 Thus, the notion of "art" is not subject to definition, at least not in the sense of analytic definitions. ${ }^{11}$ Later, supporters of such a concept pointed out that it can serve emotive, persuasive, evaluation function, etc.

However, this does not mean that, according to Weitz, it is meaningless and useless. The American author even believes that attempts to define it are not without sense, although the latter is different from what the authors of the definition assume. First of all, he points out that the term "art" can be both descriptive and evaluative. In the latter case, in the phrase "this is a work of art", the word "art" is the name of the value sought by the artists and not a statement of affiliation with a particular class of phenomena. However, what is this value and what are the characteristics of the work that make it possible to achieve it? According to the American author, this is indicated by aesthetic theories, which only seemingly have a cognitive-classification character. In fact, they highlight certain characteristics of works of art that make them interesting to the public. "It is this perennial debate over these criteria of evaluation which makes the history of aesthetic theory the important study it is. The value of each of the theories resides in the attempt to state and to justify certain criteria which are either neglected or distorted by previous theories." 12

However, the evaluative meaning of the word "art" is not always revealed indirectly and takes the form of a more or less clear definition. Sometimes the very application of this term in reference to a particular object contains a moment of positive assessment. The inclusion into the scope of the term "art" is then considered to be an ennoblement of the object, as works of art are highly regarded in society. When we talk about a cake as a "work of art", we do not perform a cognitive procedure that involves stating it has the characteristics that by definition belong to art, but we just want to express our admiration for its appearance and taste.

If we treat any definition of art created on the basis of aesthetics as a cognitive result (apart from Weitz's argumentation), we can expect it to allow us to perform several intellectual operations. Above all, it will make it possible to indicate and identify those objects that are works of art. The aim of such an indication is to confront objects with the defining characteristics of art and to

10 Ibid.

11 Władysław Tatarkiewicz argued with this view, claiming that art cannot be defined, but only in a traditional way. He therefore proposed an alternative definition that would allow us to take into account both artistic intentions and activities that appeared in different eras and lasted for a long time (What is Art? The Problem of Definition Today, "The British Journal of Aesthetics”, 1971, No 2, pp. 134-153).

12 Ibid., p. 35. 
determine whether they are present in their case. Of course, it impossible that problems will arise in border cases where not all the required properties will be found in a particular copy. Such situations, however, seemed to be rare and restricted to selected fields of art and certain artistic styles. In modern art, we know that the function of indicating and identifying by reference to definitions and related theories fails even in the case of historical examples of creativity, and any concept turns out to be too narrow or too broad in scope to identify objects that correspond to the concept of "art". In addition, indication by reference to a definition entails exclusion. According to such reasoning, the question arises: what does an object that is a work of art have that other objects do not have? ${ }^{13}$ The answer to such a problem is sought in the theory of art, from which the definition is derived. Of course, in this case, a question arises as to whether the exclusion criteria apply only to certain works, types of art or concepts predominant at certain times, or whether they are more universal in nature.

In order to carry out the aforementioned operations of indicating and excluding, it was necessary to define the notion of "art". Without such clarification, it would not be possible to carry out such procedures. It was aesthetics (also when the name was not used in the contemporary sense) that clarified such issues by formulating principles of philosophical truth about art, or rather plural, philosophical truths about art, since concepts and criteria were subject to changes in history. This generated a historical field of the notion of "art", which accompanied transformations in artistic creativity, finding expression in features attributed to works of art. Thus, referring to the formulation introduced by Arthur C. Danto (albeit in a slightly different context) and generalizing his thought, one may ask: "Instead of providing 'immediate enjoyment', does not almost all of this art appeal not to the senses but to what Hegel here calls judgment, and hence to our philosophical beliefs about what art is? So that it is almost as if the structure of the art world exactly consisted not in 'creating art again', but in creating art explicitly for the purpose of knowing philosophically what art is ${ }^{14}$ It is a vision of art derived from the perspective of its theory and stressing the role of the notion of "art". Of course, historically, real contact

13 This question refers to the problem raised by Arthur C. Dano in relation to modernist art. He wrote it: "Modernist painting, as Greenberg defined it, could only ask question „What is it that I have and that no other kind of art can have?" And sculpture asked itself the same kind of question. But what this gives us is no general picture of what art is, only what some of arts, perhaps historically the most important of arts, essentially were.” A. C. Danto, After the End of Art Contemporary Art and the Pale of History, Princeton University Press, Princeton, New Jersey 1997, p. 14. I am referring this issue, raised here on the example of painting and modernist sculpture and their relation to other ways of practicing such art, to the general notion of "art" and its relation to the non-artistic.

14 A. C. Danto, op. cit., p. 31. 
with works of art occurred differently. They were supposed to provide "direct pleasure" and serve other functions (religious, political, etc.). However, apart from that, there was also a theoretical aspect, which manifested itself in various situations. At that time the term "art" ceased to be relatively freely applied and revealed the associated indicative and excluding character. Not only did Hegel see it, but he even made it the basis of his vision of historical change. He wrote in Aesthetics, "The philosophy of art is therefore a greater need in our day than it was in days when art by itself yielded full satisfaction. Art invites us to intellectual consideration, and that not for purpose of creating art again, but for knowing philosophically what art is." 15

Hegel formulated this view in the first half of the 19th century. However, it was validated in full in the activity of the 20th century avant-garde, especially in the second half of the century. In the 1960s, as Danto wrote, artists "had that vivid sense of boundaries, each drawn by some tacit philosophical definition of art," 16 while at the same time pushing those borders and proving their impermanence. In the 1970s, they approached the problem in a more systematic way. This concerned mainly Conceptualism, but its inherent analytical inclinations were also found in representatives of other trends. Danto believes that Joseph Kosuth's idea that an artist's task is to explore the nature of art itself sounds "strikingly like the line in Hegel ['s]" Aesthetics that art encourages us to reflect upon what art is, not to create new works of art, but to learn scientifically what art is. ${ }^{17}$ The difference, however, is that the American artist referred in his view not to the way he perceived works of art, but to their creation. Inquiring about the nature of art itself, defining it, was an artistic proposal that was reflected in creative methods, such as the principle of tautology.

The best example of the use of this concept is Kosuth's work from the late 1960s and early 1970s. In a series of works entitled Art as Idea as Idea, definitions of the term "art", as well as other related concepts, became the material of artistic activities. The starting point, as the artist stated in an interview given to Jeanne Siegel, was the creative "motto" by Ad Reinhardt, which was a kind of a definition of art he adopted: "Art-as-Art". However, it entailed problems of shaping the form. Kosuth, on the other hand, believed that art was an idea. However, the phrase "Art as idea" also contained an element of reification, because the idea was treated similarly to an object, so there was no liberation from the formalistic ideology of art. Hence, the second part of the title. "The addition of the second part - "Art as Idea as Idea" - intended to suggest that the real creative process, and the radical shift, consisted in changing the idea of

15 G. W. F. Hegel, Aesthetics, cited in ibid., p. 31.

16 A. C. Danto, op. cit., p. 14.

17 Ibid., p. 13-14. 
art itself. In other words, my idea of doing that was the real creative context," 18 Kosuth said. The rethinking of the idea of art, i.e. the thought process, was meant to become the starting point for an activity in which thinking plays a fundamental role. The series consists of large photocopies of dictionary definitions of terms referring to art, such as "idea", "painting", etc., hung on gallery walls (similarly to paintings). These are the components of the process of thinking/ creating. Titles of the individual works are terms whose definitions we learn while watching/reading them. As Kosuth put it, "It was titled already within the work, so I just titled the title". 19

One can probably agree that Kosuth's concept is a consistent proposal of practicing art after the death of art - after Hegel's transition from creating works of art to considering what art is. The originality of this proposal, however, lies in the fact that art here both died and still lives. In Conceptualism, it did not become a closed chapter in the sense of the end of the process of producing works, but a way of cultivating creativity, making the notions and definitions of "art" a way of practicing creativity. Had such an orientation occurred earlier? In his text Art after Philosophy, Kosuth pointed this out when writing that "One can certainly see a tendency toward this self-identification of art beginning with Manet and Cézanne through to Cubism." ${ }^{20} \mathrm{He}$ added, however, that those attempts were timid and vague. He attributed a fundamental meaning to Duchamp ready-made, because only in it did "art changed its focus from the form of the language to what was being said," "it changed the nature of art from a question of morphology to a question of function," and a transition occurred "from 'appearance' to 'conception." 21 All these activities focused on how to make the concept of 'art' a component of a work of art, rather than an external element used to categorize it, indicate it and distinguish it from other objects. At the same time, art understood thus closed itself off and became a kind of game between a work of art and the notion of "art".

Defining the term "art" does not have to be identified with the artistic process. It is possible to consider a situation in which the two undertakings are treated as two separate activities interlinked by a complex system of interdependencies. This was the case with the main avant-garde trends, which usually include Dadaism, Surrealism and Constructivism. Within each of them, attempts were made to grasp the truth about art understood in a broad, philosophical

18 Art as Idea as Idea: An Interview with Jeanne Siegel, [in:] J. Kosuth, Art after Philosophy and After. Collected Writings 1966-1990, ed. G. Guercio, The MIT Press, Cambrudge, Massachusetts 1993, p. 47.

19 Ibid., p. 48.

20 J. Kosuth, Art after Philosophy, [in:] Ibid., p. 18.

21 Ibid. 
sense, and to put that truth into practice. Usually, such implementation was limited to the performance of such works that would become a materialization of theoretical findings on art, which were formulated in manifestos. Therefore, as Danto rightly points out, written manifestoes should be considered an integral part of avant-garde art.

Research on the avant-garde carried out over the past decades has also taken into account the issue of manifestos. There are even specific rules of manifesto poetics, which usually stress that they are texts containing program principles published in a journal or as an independent publication, they address a specific social group (e.g. the youth, the proletariat) and justify the artistic practice of a given group. Manifestos may also contain theoretical generalizations. The concept of a manifesto on which I would like to focus is understood in a broader sense. I am referring to Danto's comment, "The manifesto defines a certain kind of movement, and a certain kind of style, which the manifesto more or less proclaims as the only kind of art that matters." 22 This wording brings to the fore what in the concepts of manifesto poetics is treated as an extra factor. A manifesto is a certain way of defining art by indicating what true art is. Examples are given of such works, as well as of other works that are negated or criticized. Thus, manifestos define "art", which can be compared to the formulation of a projecting definition on the basis of science. It is usually characterized as different from analytic definition. It is not an attempt to convey the existing scope and sense of a specific term, but consists in a "terminological project". Therefore, the full text should start with the following: "May the word ' $\mathrm{x}$ ' mean..." The term " $\mathrm{x}$ " may exist in a given language, and then the projecting definition is an attempt to clarify its meaning, but it may just as well not exist, and then we are dealing with a new terminological proposal. If such a term does exist, the projecting definition may partially change its scope or meaning.

Danto stresses that avant-garde artistic manifestoes (in the broad sense, as mentioned above) do not usually have a structure proper to the definition. Instead, they take on the form of a narrative. These may be narratives resembling reflections on the history of art, philosophical, social, political narratives, etc. Of course, the main subject of the manifestoes are the proposed concepts of true art (i.e. the one advocated by authors of the text), but apart from that, there are also examples of other artistic concepts, assessed negatively, as well as references to unspecified "art as such". Its characteristic is that it never changes. Danto writes: "The picture then is this: there is a kind of transhistori-

22 A. Danto, op. cit., p. 28. Danto considers theoretical texts by Malevich, Mondrian and Reinhardt to be manifestos in the above sense, as well as Clement Greenberg's articles, which can be treated as manifestoes of modernist painting and sculpture. 
cal essence in art, everywhere and always the same, but it only discloses itself through history. This much I regard as sound. What I do not regard as sound is the identification of this essence with a particular style of art - monochrome, abstract, or whatever - with the implication that art any other style is false. This leads to an ahistorical reading of the history of art in which all art is essentially the same - all art, for example, is essentially abstract - once we strip away the disguises, or historical accident that do not belong to the essence of 'art-as-art."”23

"The Age of Manifestos", as Danto calls it, was a period of proclaiming a great series of such concepts. The American author ties this to the historicism characteristic of Modernism. However, the present, according to the American author, posthistoric moment in art history requires a completely different practice. That is why manifesto writing is over. Not because, as other authors claim, the great diversity of contemporary art makes it impossible to bring more artists together under common mottos, but because the belief in the existence of "art-as -art” has declined. ${ }^{24}$ Danto claims that art can be everything artists and patrons want it to be. And I do not think that this statement should be interpreted as a support for the institutional concept of art formulated by George Dickie. It is rather the result of a more general reflection on the changes that took place in the 20th century and whose effects are only now visible. "For the past century," Danto writes, "art has been drawing toward a philosophical self-consciousness, and this been tacitly understood to mean that artists must produce art that embodies the philosophical essence of art. We now can see that this was a wrong understanding, and with a clearer understanding comes the recognition that there is no further direction for the history of art to take." ${ }^{25}$ It is a pluralistic world, whose principles of existence, however, the methods proposed by the supporters of pluralistic aesthetics are unable to grasp. Research methods based on partial definitions are also not so much unreliable as they do not lead to further cognitive results. What is important, however, is the coexistence of a great number of various proposals, which are referred to as "art".

Danto describes the situation after the end of the Age of Manifestoes as the "end of art". He believes that the Age of Manifestoes has come to an end because the foundations of art guided by manifestos are unsustainable today.

23 Ibid., p. 28-29.

24 "A manifesto," Danto writes, "singles out the art it justifies as the true and only art, as if the movement it expresses had made the philosophical discovery of what art essentially is. But the true philosophical discovery, I think, is that there really is no art more true than any other, and that there is no one way art has to be: all art is equally and indifferently art. (ibid., p. 34).

Ibid., p. 36. 
Meanwhile, philosophical reflection on art, even when concepts formulated within its framework are too narrow and based on generic or historical premises (for which Weitz criticized them), aims at formulating a theory that would cover all artistic phenomena. Therefore, according to Danto, "the mentality that expressed itself in manifestos sought in what it supposed was a philosophical way of distinguishing genuine questions from pseudo-questions. Pseudoquestions appear to be genuine and crucial, but they are questions only in the most superficial grammatical sense." ${ }^{26}$ This variety of thinking about art and practicing art is over. The American author believes, however, that this does not mean the disappearance of the possibility of evaluation and the need to recognize that every product or activity proposed as artistic is art. The only thing that lost its legitimacy is the approach based on the assumption that "goodness and badness are (...) matters of belonging to the right style", or "falling under the right manifesto.". "That is what I mean," he writes, "by the end of art. I mean the end of a certain narrative which has unfolded in art art history over the centuries, and which has reached its and in a certain freedom from conflicts of the kind inescapable in the Age of Manifestos.”27

The situation after the end of art (understood as described above) is characterized by a greater sense of freedom. The purpose of the concept of "art" is no longer to indicate what proper artistic activity is and exclude everything that is not covered in the theory proclaimed by the manifesto constructed one way or another. It begins to be characterized by openness, but understood differently and more broadly than Weitz assumed, inspired by Wittgenstein's concept. The openness of the term "art" refers not only to research on it, but it also has a practical aspect and concerns creativity that is not limited to the hitherto conceptual ranges defined by aesthetic and artistic theories. Danto links it to the belief that the "coexistence" in the undefined sense of the term "art" will be more peaceful because there will be no "ethnic cleansing". Thus, he has an optimistic outlook on the situation "after the end of art". However, a question arises as to whether this is not another utopia, this time positive. After all, the above analysis completely overlooks the role of institutional factors affecting art and, above all, the influence of the art market. I do not intend to address the role of these factors and their impact on "coexistence" in the artistic sphere at the moment. Instead, I would like to draw attention to what is happening within the contemporary free and open scope of the term "art".

As an example, I will consider the concept of "art with community", which has been the subject of growing interest for several years now. It refers to the idea of relational art, participatory art and, above all, to the British idea of com-

26 Ibid., p. 34.

27 Ibid., p. 37. 
munity arts. However, I will take into account not so much the character of the actions themselves, as the theoretical reflection that accompanies them and the way in which the term "art" functions therein. The phrase "art with community" is used, among others, as the name of practices undertaken since 2011 with the local community of Warsaw's Ursus district. Until the economic transformation in Poland post-1989, there had been a large tractor factory there, which later went bankrupt. Former workers had problems finding a new job or a place for themselves within the new social system. A group of people (artists, art theoreticians and organizers of cultural events) took action in that environment "with the help of tools from the field of art, in a way that positively affects the quality of life there." ${ }^{28}$ It usually involved various types of actionist proposals with the participation of representatives of the local community, originating from and manifesting in areas such as visual arts, performative practices, movement and dance, film and music. This activity is consistently referred to as art. What are the reasons for applying that name and how is this justified?

Practices realized in Ursus have been encapsulated with statements describing particular activities, as well as theoretical articles. However, there is no text among them that could be considered a manifesto in the sense previously outlined herein. Therefore, it is not possible to formulate theses that would contain program principles. There is also no clear statement that this is true art, grasping the truth of art, etc. Instead, emphasis is placed on practical effects these actions have on the participants and the belief that this is so close to everyday life that it becomes almost indistinguishable from art. I think that many observers of such activities, as well as their participants, are not fully aware of the fact that they are taking part in artistic creativity. They may think that it is a form of social activity based on socio-cultural or educational activation. In the formulated principles of such activity, social objectives are intertwined with artistic ones. "We believe that this effort is worth undertaking, because we believe that art with community has an extraordinary potential to respond to the threats related to the shrinking democracy, the disappearance of social empathy-based empowerment practices, and is also a response to the lack of identification of societies with contemporary art." 29

How is the artistic character of this activity indicated? The main aim is not to consider the relationship between the set of qualities that characterize "art with community" and those that are typical of similar generic terms in a given field (in order to formulate a partial definition), or to confront them with the definitional properties of the general concept of art. Such an approach has

28 J. Wójcik, I. Stokfiszewski, I. Jasińska, Wprowadzenie, [in:] Sztuka ze społecznościa, ed. J. Wój29 cik, I. Stokfiszewski, I. Jasińska, Wydawnictwo Krytyki Politycznej, Warszawa 2018, p. 7.

Ibid., p. 9. 
traditionally been applied both in the case of manifestos and scholarly analyses of the term "art". They were characterized by a way of thinking that could be described as vertical because it was based on the principle of relations between generic categories and concepts with a lesser degree of generality. Meanwhile, in this case, the approach is horizontal, resembling a game of dominoes. It is based not on the subordination of the less general to the more general, but on a comparison, so to speak, of the boundary values of individual elements. As in the case of dominoes, where the number of points of the adjacent tile must be the same, such considerations are intended to show the partial compatibility of the components to be matched. The result is not a two-story construction (reminiscent of a tree) composed of artistic notions, but an expandable network of interdependencies. ${ }^{30}$

An example of such an approach to the discussed issue can be found in an article by Igor Stokfiszewski entitled Sprawczość wspólnoty. W stronę radykalnego programu sztuki ze spotecznościa [Community agency. Towards a radical program of art with community]. The author opens the text with Claire Bishop's concept of "social turn", which means engaging people in creative processes. Under this concept, an engaged variant of such practices is indicated, which includes the varieties described as community art, dialogic art, interventionist art or participatory art. Then, theatrical variety is introduced, and community theatre, social theatre or engaged theatre are listed. What unites the two groups is the role of the participatory factor. Thus, music and film of such character are evoked. Since the role of space is sometimes taken into account in the activities, the author mentions site-specific art. As a common feature of these practices, the author points to the "desire to democratize art" ${ }^{31}$ However, this phrase directs attention towards a very broad category, which is realized in a very different way, both in art and beyond. In any case, he does not expound on the subject, nor does he address the problem of the relationship between the democratization of art based on the principles of participation and other forms of democratization. Instead, he moves on to the issue of this phenomenon in Central and Eastern Europe, where the democratic impulse at some point lost its momentum and needs to be re-programmed.

The next subchapter features a phrase that can be regarded as an attempt to define the phenomenon in question: "Thus, art with community is an artistic

30 The issue I am addressing is somewhat reminiscent of the rhizome principle, discussed by Deleuze and Guattari, although it is less radical. In the domino principle, there is no beginning and no end, there is unlimited expanse, but the variety of elements is limited by the need for similarity of those that are directly adjacent to one another. At the moment, I cannot provide any broader discussion of this issue.

31 I. Stokfiszewski, Sprawczość wspólnoty. W stronę radykalnego programu sztuki ze spotecznościa, [in:] Sztuka ze spotecznościa, op. cit., p. 16. 
practice of counter-cultural origin, oriented towards processual work with the local community in order to equip it with instruments of self-emancipation." 32 Immediately afterwards, however, the author returns to discussing adjacent categories. He considers names such as "art of community", "art (for) community" or "art for small communities" (which he derives from different translations of the English phrase "community arts" into Polish) and contemplates to what circles of meaning they refer. He cites Joseph Beuys's donation to the Museum of Art in Łódź (Polentransport 1981) and points out that the beneficiaries were not involved in its production. Thus, there is only a partial resemblance to the situation that takes place in the case of "art for community". Then he considers artistic activities in the Gdańsk Shipyard inspired by Grzegorz Klaman and Aneta Szyłak, where art soaked up inspirations from other areas instead of affecting them. He then cites the example of Eugenio Barba's "third theatre", in which active culture is emphasized. This way, shifts in and around the discussed area are shown, but there are no questions about borders or identity issues. Perhaps, then, these issues are no longer relevant to the contemporary consideration of the notion of "art"?

The discussed example of theoretical behavior in the extended, open field of art is not a research project based on a new pattern or model. In my opinion, Karen Raney, author of the book Art in Question, a collection of interviews with artists, art researchers and curators, who wrote about "theorizing with uncertainty", may be quoted in this case. ${ }^{33}$ This is how she defines contemporary artistic reflection. The ingredients that were supposed to give it a sense of stability have been contested. The use of an established system of concepts and verified methods has been questioned. Instead, as the author claims, we are dealing with the acceptance of conflicts and inconsistencies. "The tendency now is to want to preserve this turbulence and work within it - to see it as the point of departure - rather than prematurely to try to settle it." ${ }^{34}$ We feel that confusion, tension and subversion are more creative and, first and foremost, they do not impose any limits. Conflict becomes a constant process in art. Therefore, no attempts are made to organize concepts and their analytical definition. Apart from the fact that such actions would not be feasible in principle, it is the game that is more appreciated, not analysis. Under-interpretation or over-interpretation becomes an accepted course of action.

In an attempt to characterize the thinking that dominates in contemporary reflection on art, Raney also uses the phrase "in between and to and fro".

32 Ibid., p. 18.

33 Art in Question, ed. K. Raney, The Arts Council of England - Continuum, London - New York 2003, p. 6.

34 Ibid., p. 9. 
First of all, binary oppositions are rejected. However, the applied categories are reworked in such a way as to make them more dynamic. If, twenty or thirty years ago, the progressing process of hybridization was pointed out, which consisted in combining and permeating artistic phenomena and the range of notions used to talk about them (similarly as the features of biological species are mixed up under certain conditions), today it is believed that we are dealing with a more dynamic situation. Hybridization is a long-term process, leading to the creation of relatively permanent forms, whereas the current mixing of artistic phenomena and notions is fast and rather without any tendency to consolidate. The danger, however, is polarization. In order to counteract it, everything operates in the gap, constantly moving back and forth. ${ }^{35}$

Given the situation described here, is the concept of "art" necessary? As I have stressed, in traditional artistic deliberations it had rather a stabilizing function. Later, in the Age of Manifestoes, various ways of defining art were meant to contribute to making it more dynamic. In both cases, however, polarization of positions was important. I believe that today the term "art" has changed its character. I think that its main function is integrative. This notion, which is quite commonly perceived as open, makes it possible to include various phenomena in the previously indicated ranges, which otherwise would be difficult to name. When they appear in the field of art, they enter an interpretative game and are subject to attempts of incorporation into existing artistic categories, differentiation from them, reformulation of their meaning under the influence of new factors, etc. They are also subject to the rules of the art world. Moreover, the integrative sense is not limited to conceptual issues, but also has consequences for those who participate in it. The term "co-existence within art" also includes participants in a variety of "artistic games" - artists, audiences and art theorists alike.

\section{BIBLIOGRAPHY:}

Aesthetics and Language (1954) ed. Elton W., Oxford: Basil Blackwell.

Art in Question (2003) ed. K. Raney, London - New York: The Arts Council of England - Continuum.

Bürger Peter (1984) Theory of the Avant-Garde, transl. M. Shaw, Minneapolis: Manchester University Press - University of Minnestota Press.

Danto Arthur C (1997) After the End of Art. Contemporary Art and the Pale of History, Princeton, New Jersey: Princeton University Press.

35 Ibid., p. 15. 
Dziemidok Bohdan (2002) Gtówne kontrowersje estetyki wspótczesnej, Warszawa: Wydawnictwo Naukowe PWN.

Kosuth Joseph (1993) Art after Philosophy and After. Collected Writings 1966-1990, ed. G. Guercio, Massachusetts: The MIT Press, Cambrudge.

Morawski Stefan (1985) Na zakręcie. Od sztuki do posztuki, Kraków: Wydawnictwo Literackie.

Oliva Achile B. (1988), Superart, Milan: Giancarlo Politi Editore.

Sztuka ze społecznościa (2018) ed. J. Wójcik, I Stokfiszewski, I. Jasińska, Warszawa: Wydawnictwo Krytyki Politycznej.

Weitz Moritz (1956) The Role of Theory in Aesthetics, "The Journal of Aesthetics and Art Criticism”, No 1.

\section{DLACZEGO JEST NAM POTRZEBNY TERMIN „SZTUKA”? (streszczenie)}

W artykule podjęta została refleksja nad współczesną sytuacją, w której termin „sztuka” jest szeroko stosowany, ale bez podejmowania prób uściślenia jego znaczenia lub definiowania go. Sytuacja ta dotyczy zarówno obszaru estetyki, gdzie rozważania nad pojęciem sztuki zanikły od kilku dekad, jak wypowiedzi krytyków i artystów.

Punktem wyjścia prowadzonych tu rozważań jest stan, jaki miał miejsce w latach 50. i 60. XX wieku. W myśli estetycznej pojawiły się wówczas poglądy wskazujące na niedefiniowalność pojęcia „sztuka” (np. stanowisko Morrisa Weitza) oraz tendencje do wskazywania innych sposobów użycia tego terminu, niż poznawczy - uwzględnienia jego charakteru oceniającego, perswazyjnego itp. W latach 90. ważnym głosem w tej sprawie były teksty Arthura C. Danto, który ujmował zagadnienie w kontekście swojej teorii „końca sztuki”. Koniec ten nie oznaczał kresu twórczości artystycznej, a tylko zmianę polegającą na zakończeniu się ery sztuki jako problemu teoretycznego. W XX wieku zarówno w tworzonych dziełach, jak pisanych tekstach, próbowano ustalić, czym jest „sztuka prawdziwa”. Dziś natomiast wszystkie znaczenia słowa „sztuka” stają się ważne. Życie artystyczne, według Danto, układa się więc bardziej pokojowo, bez „czystek etnicznych".

Jak zatem motywuje się włączanie poszczególnych praktyk do obszaru sztuki? Uważam, że często następuje to na zasadzie podobnej do gry w domino. Ilustruję tę tezę za pomocą polskiego przykładu - koncepcji „sztuki ze społeczeństwem” realizowanej od 2011 roku w warszawskiej dzielnicy Ursus. Tekst kończą refleksje odnoszące się do współczesnego „teoretyzowania z niepewnością”. Pojawia się teza, że termin „sztuka” pełni dzisiaj przede wszystkim rolę integrującą wobec różnorodnych działań, dla których inaczej trudno byłoby znaleźć stosowną kategorię.

Słowa kluczowe: niedefiniowalność pojęcia „sztuka”, „koniec sztuki” (A. Danto), sztuka po końcu sztuki, teoretyzowanie z niepewnością, „sztuka” jako kategoria integrująca 
Grzegorz Sztabiński - Professor at the Faculty of Visual Arts in the Strzemiński Academy of Arts in Łódź, where he is head of the Department of Theory and History of Art and Studio of Intermedial Composition. Professor in the Department of Art History at the University of Łódź. His theoretical research focuses on the philosophy of modern art and issues of contemporary aesthetics. His publications include three books on these subjects, four edited collections and over 200 articles in Polish and foreign journals. He also writes critical reviews. He has been a member of AICA (Association Internationale des Critiques d'Art) since 1995 and has participated in the boards of academic journals and art galleries. Concurrently with his academic work, he is an author of paintings, drawings, installations, and a number of performances. His work was shown in some 70 solo exhibitions in Poland and abroad; he has also taken part in many collective Polish and international exhibitions (e.g. the Săo Paulo Art Biennial (1979); the International Triennial of Drawing in Wrocław (1978, 1981,1988, 1992, 1995); the Symposium of Systematic and Constructive Art in Madrid (1989). 